черной // Плодоводство и ягодоводство России. 2008.

Т. 18. С. $141-155$.

16. Абдуллаева Э.В., Рамазанова А.Р. Особенности размножения туи западной черенкованием // Субтропическое и декоративное садоводство. 2011. № 45. С. 156-159.

17. Зубарев Ю.А., Гунин А.В., Воробьева А.В. Развитие корневой системы трудноокореняемых сортов облепихи при зеленом черенковании с использованием различных концентраций стимуляторов корнеобразования // Современные тенденции развития аграрного комплекса. 2016. С. 839-844.

18. Вьюгин С.М., Вьюгина Г.В. Использование синтетических аналогов растительных гормонов при зеленом черенковании декоративных кустарников // Защита и карантин растений. 2016. № 10. С. 47-48.

19. Усенко В.И., Цымбалюк М.А. Эффективность обработки маточных растений и зеленых черенков стимуляторами роста при размножении жимолости // Достижения науки и техники АПК. 2009. № 5. С. 28-30.
20. Рахматова Н.Р. Особенности ризогенеза при черенковании некоторых интродуцированных видов Ligustrum L. // Вестник Воронежского государственного университета. Серия: География. Геоэкология. 2010. № 2. С. 79-81.

21. Васильева О.Ю. Онтоморфологические особенности семенных и клоновых подвоев садовых роз в условиях Сибири // Сибирский вестник сельскохозяйственной науки. 2008. № 1. С. 52-59.

Интродукционные эксперименты по изучению особенностей каллусо- и ризогенеза проведены в рамках следующих научных проектов: в 20132016 z2. проект VI.52.1.7. "Изучение адаптивного потенциала полезных растений ех situ: биоморфология, онтоморфогенез, репродуктивная биология" (номер проекта в ИСГЗ ФАНО: 0312-2014-0007); с 2017 2. по настоящее время проект VI.52.1.3. «Выявление путей адаптации растений к контрастным условиям обитания на популяционном и организменном уровнях" (номер госрегистрации AAAA-A17-117012610053-9).

\title{
METHODICAL ASPECTS OF VARIOUS BIOMORPHS ORNAMENTAL PLANTS REGENERATION STUDY
}

(C) 2018

Vasilyeva Olga Yurievna, doctor of biological sciences, head of Ornamental Plants Introduction Laboratory Sarlaeva Inna Yanovna, junior researcher of Ornamental Plants Introduction Laboratory Central Siberian Botanical Garden of Siberian Branch of Russian Academy of Sciences

(Novosibirsk, Russian Federation)

\begin{abstract}
The paper raises the problem of conservation, maintenance, rejuvenation and accelerated reproduction of plant objects in bioresource collections using green cutting propagation. The authors describe experimental methods of herbaceous and woody plants regeneration study in agricultural, physiological-biochemical and morphological directions. In agricultural direction the main factors are the timing and methods of green cutting, as well as the microecological conditions in which regeneration takes place (humidity, temperature of the air and substrate). The physiological and biochemical aspect concerns the use of various growth stimulants, including concentrations and timing for the treatment of unruly cuttings. The reliable positive effect of the growth stimulants in comparison with control natural regeneration can be proved by the t-criteria. The morphological aspect shows features of callusogenesis and rhizogenesis. The most profound analysis is possible when representatives of generic complexes, species and varieties of various ecological, geographical and genetic origin are involved in the experiment. A highly informative classification of callusogenesis and rhizogenesis proposed by N.F. Dovbysh, N.A. Oleinik and G.A. Kudina (1993) is described in detail; in this classification three types of callus implantation are described: circular, focal and continuous, as well as five types of localization and development of roots. Root formation can occur 1) in the zone of the node, 2) from the callus tissue, 3) from the side of the bud and leaf trail, 4) over the entire surface of the internode, as well as 5) mixed (from the tissues in the node zone and from callus tissue). Based on the long-term study of the regeneration of shrub and herbaceous ornamental plants, the authors of the paper propose one more type - in the entire surface of the lower cut.

Keywords: callusogenesis; rhizogenesis; variance analysis; estimation of significance of difference of sample means by t-criteria; green cutting; artificial fog; growth stimulants; garden roses; Phlox paniculata; Chrysanthemum koreanum; Hydrangea paniculata; Lonicera caerulea; forest-steppe zone of West Siberia.
\end{abstract}

УДК 582.594:58:502.75 (571.14)

DOI 10.24411/2309-4370-2018-14104

Статья поступила в редакцию 03.07.2018

\section{РОД CYPRIPEDIUM L. В УНИКАЛЬНОМ МЕСТООБИТАНИИ ОРХИДНЫХ В НОВОСИБИРСКОЙ ОБЛАСТИ}

(C) 2018

Герасимович Людмила Владимировна, кандидат биологических наук, младший научный сотрудник лаборатории интродукции декоративных растений Центральный сибирский ботанический сад СО РАН (2. Новосибирск, Российская Федерация)

Аннотащ̧ия. В статье приводятся сведения об уникальном местообитании, где произрастает 13 видов орхидных из родов Dactylorhiza Nevski, Epipactis Zinn, Gymnadenia R. Br., Herminium R. Br., Orchis L., Platanthera L.C.M. Rich., Cypripedium L. в Искитимском районе Новосибирской области. Дано морфологиче- 
ское описание трех видов башмачков, включая новый вид для Новосибирской области Cypripedium $\times$ ventricosum Sw., который предлагается включить в Красную книгу Новосибирской области. Исследуемое сообщество башмачков расположено в березово-высоко-разнотравном лесу, в бассейне реки Койниха. Проведено сравнение описанных в результате мониторинга характеристик вегетативных и генеративных органов Cypripedium $\times$ ventricosum Sw., Cypripedium calceolus L. и Cypripedium macranthon Sw. с литературными данными. Показано, что у C. calceolus все параметры, за исключением длины прицветника (превышающей средние показатели), входят в описанный диапазон. У C. macranthon и $C$. $\times$ ventricosum в изученном местообитании большинство параметров (длина и ширина прицветника, длина и ширина бокового листочка околоцветника внутреннего круга) имеют более высокие значения. Это позволяет сделать вывод, что экологоценотические условия исследуемого местообитания являются наиболее благоприятными для C. macranthon и C. $\times$ ventricosum. Ценопопуляции всех трех видов существуют достаточно продолжительный срок и находятся в своем реальном оптимуме.

Ключевые слова: Семейство Orchidaceae Juss.; Cypripedium × ventricosum Sw.; Cypripedium calceolus L.; Cypripedium macranthon Sw.; новый вид для Новосибирской области; Искитимский район; сравнительная морфология; мониторинг; охрана редких видов; Красная книга Новосибирской области.

\section{Введение}

Орхидные, или Ятрышниковые, - крупнейшее семейство класса однодольных, включает свыше 750 родов и 25 тысяч видов многолетних трав, лиан, произрастающих на всех континентах, в различных зонах и поясах, за исключением полярных и пустынных областей. Среди тропических орхидных немало эпифитов с воздушными, в том числе фотосинтезирующими корнями [1]. Согласно данным Н.К. Ковтонюк [2, с. 447-456], во флоре Западной и Восточной Сибири семейство Orchidaceae Juss. представлено 23 родами (в том числе в Республике Алтай - 31 вид из 17 родов, в Новосибирской области - 26 видов из 18 родов).

Изучение эколого-биологических особенностей орхидных было начато нами в Горном Алтае в 2000 г. на неохраняемых территориях с разной степенью антропогенной нагрузки. Было выявлено [3, c. 68], что наиболее крупными центрами видовой насыщенности (за пределами заповедников) здесь являются долины рек Мульта, Кураган, Кучерла (12 видов), окрестности с. Чемал (11 видов), устье p. Чулышман, окрестности оз. Манжерок, долина р. Мена (10 видов).

С 2011 г. исследования были продолжены в Новосибирской области (НСО), и начиная с 2012 г. нами проводится мониторинг нового уникального местообитания орхидных в Искитимском районе $\mathrm{HCO}$, где произрастают 13 видов из 7 родов. Объектами исследований являются Dactylorhiza cruenta (O.F. Muel.) Soo`, D. incarnata (L.) Soo`, D. fuchsii (Druce) Soo`, D. maculate (L.) Soo`, Epipactis helleborine (L.) Crantz, E. palustris (L.) Crantz, Herminium monorchis (L.) R. Br., Gymnadenia conopsea (L.) R. Br., Platanthera bifolia (L.) Rich., Orchis militaris L., Cypripedium macranthon Sw., Cypripedium calceolus L. и образованный ими гибридный вид Cypripedium $\times$ ventricosum $\mathrm{Sw}$.

Cypripedium $\times$ ventricosum для $\mathrm{HCO}$ конкретно описан не был, в «Определителе растений Новосибирской области» [4, с. 388] данный вид не указан. Во «Флоре Салаирского кряжа» [5, с. 174] отмечается, что C. macranthon «Образует гибриды с C. calceolus L.». Гербарные образцы в ЦСБС СО РАН до 2018 года отсутствовали.

Род Cypripedium до настоящего времени вызывает большой интерес отечественных систематиков. При его изучении, в том числе и с применением молекулярно-генетических методов, неоднократно пы- тались определить, является ли $C$. × ventricosum гибридогенным видом в стабильном сотоянии, а также насколько C. shanxiense X.-Q. Chen в таксономическом отношении отличен от $C$. calceolus L. По имеющимся к настоящему времени данным [6], видовой статус $C$. shanxiense подтверждается, а $C$. ventricosum нет четких проявлений в качестве самостоятельного вида.

Цель исследований - выявить особенности представителей рода Cypripedium L. в условиях $\mathrm{HCO}$ и описать Cypripedium $\times$ ventricosum $\mathrm{Sw}$. для включения его в Красную книгу Новосибирской области.

\section{Методика исследований}

Уникальное местообитание орхидных находится в окрестностях села Линёво Искитимского района HCO (54²8'27,9" с.ш., 83²19'41,4" в.Д., 190 м над ур. м.). Исследуемое сообщество башмачков расположено в березово-высоко-разнотравном лесу. Описания

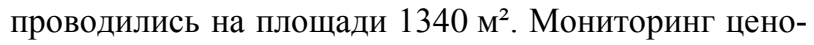
популяций осуществляется с 2012 г. по настоящее время. Онтогенетические состояния определялись по T.А. Работнову [7] и А.А. Уранову [8]. При описании ценопопуляций также использовали методику, предложенную Л.В. Денисовой, С.В. Никитиной, Л.Б. Заугольновой [9], и методические подходы Л.Б. Заугольновой, А.А. Жуковой, А.С. Комаровой, О.В. Смирновой [10].

\section{Результаты исследований и их обсуждение}

На сегодняшний день для Новосибирской области известно одно компактное и массовое местопроизрастание тринадцати видов из семейства Orchidaсеае, расположенное в бассейне реки Койниха в окрестностях поселка Линёво [11]. В России подобное местообитание есть лишь в Тверской области, где уникальными природными комплексами с максимально широким представительством видов орхидных являются «Старицкие ворота» и «Вышневолоцко-Новоторжский вал» [12].

В данной работе наиболее полно представлены сравнительные исследования трех видов рода Cypripedium - Cypripedium calceolus L., C. macranthon Sw. и Cypripedium $\times$ ventricosum $\mathrm{Sw}$.

В системе классификации рода C. calceolus и C. macranthon относят к двум разным подсекциям, отличающимся морфологией цветка, $-C$. subsect. 1 Cypripedium и C. subsect. 2 Macrantha, соответственно. C. × ventricosum включен во вторую подсекцию [13]. 


\section{Род Башмачок-Cypripedium $\mathbf{L}$.}

1. Губа светло-желтая, короче остальных бурых ланцетных листочков околоцветника, из которых боковые скрученные по оси

\section{Б. известняковый - C. calceolus $\mathrm{L}$}

+ Губа другого цвета

2. Губа розово-фиолетовая однотонная

Б. крупноцветковый - C. macranthon $\mathrm{Sw}$.

+ Губа буровато-розовая или коричнево-бордовая с темными жилками или другого оттенка плоть до почти белого цвета

Башмачок вздутый - C. $\times$ ventricosum $\mathrm{Sw}$.

Cypripedium calceolus L. 1753 [14, c. 951; 15, c. $598 ; 16$, c. $127 ; 4$, c. $388 ; 17$, c. $379 ; 18$, с. $501 ; 19$, c. 345] - Башмачок известняковый, настоящий.

Короткокорневищный многолетник высотой от 30 до 60 см. Корневище горизонтальное толстое, с жесткими корнями. Настоящих 3-4 листа, овальноэллиптической формы, заостренных на конце, 1315,5 см длиной и 4-10,5 cм шириной, железистоопушенные, с обеих сторон и по краю немного волосистые. Прицветники листовидные 7,5-9,5 см длиной, 2,5-5,5 см шириной. Цветки по одному или два в соцветии. Листочки околоцветника, кроме губы, коричнево-бордовые. Верхний листок наружного круга околоцветника эллиптически-ланцетный, с жилками, 3,5-5,5 см длиной и 1,0-2,0 см шириной. Два боковых листочка наружного круга околоцветника срастаются в так называемый сенсепалум, чаще не до конца сросшийся и располагающийся под губой. Листочки внутреннего круга узкие и перевитые, 4,0-5,1 см длиной и 0,4-0,5 см шириной, длиннее губы. Губа вздутая, желтого окраса разной интенсивности, внутри волосистая с красноватыми крапинками, снаружи голая, 3,0-3,5 см длиной и 1,5-2,0 cм шириной. Тычинки и столбик с рыльцем бледножелтые. Стаминодий белый, с пурпурными крапинами, 0,8-1,3 см длиной. Завязь железисто-опушенная, не скрученная 2,2-3,5 см длиной, 0,5-0,7 см шириной. (рис. 1: 1).

Cypripedium macranthon Sw. - Cypripedium macranthos Sw., 1800, Kongl. Vetenskaps Acad. Nya Handlingar 21: 251; - Cypripedium macranthum Sw. [20, c. $251 ; 15$, с. $598 ; 16$, с. $127 ; 4$, с. $388 ; 17$, с. $379 ; 18$, c. $501 ; 19$, с. 346 - Башмачок крупноцветковый.

Короткокорневищное многолетнее растение. Корневище темно-бурое, горизонтальное с многочисленными шнуровидными корнями. Высота одноцветковых побегов 29-50 см; в базальной части их находятся чешуевидный лист бурого или белого цвета, редко два. Очередных листьев 3-5, 11-19 см длиной, 5,0-12,0 см шириной, широкоэллиптические, заостренные, по жилкам и краю слегка волосистые. Наибольшие размеры имеют листья срединной формации. Листовидный прицветник 9-14,2 см длиной и 3,5-8,5 см шириной. Околоцветник розовый с лиловыми или фиолетовыми оттеками и темными жилками. Листочки неравнобокие, яйцевидно-ланцетные, равны или чуть длиннее губы. Верхний листок наружного круга околоцветника 4,5-5,2 см длиной и 3,3-4,0 см шириной. Два боковых листочка наружного круга образуют двузубчатый сенсепалум, расположенный сзади губы. Два листочка внутреннего круга, располагающихся по бокам губы, с ровными краями, 4,9-6,5 см длиной, 1,9-2,7 см шириной. Губа с морщинистой поверхностью 4,0-6,5 см длиной и 3,0-5,0 см шириной, сильно вздутая, с небольшим отверстием, края которого образуют оторочку, заворачиваясь внутрь. Тычинки и стаминодий беловатые, последний с фиолетово-пурпурными крапинками, до 1,2-1,8 см длиной. Завязь железисто-опушенная, нескрученная $2,5-3,5$ см длиной $0,4-0,5$ см шириной (рис. 1:2)

Cypripedium $\times$ ventricosum Sw. - Cypripedium ventricofum - 1800. [20, c. 251; 21, c. 35] - Башмачок вздутый, вздутоцветковый.

Короткокорневищное многолетнее растение. Корни многочисленные жесткие. Побеги 27-60 см высотой, с простым или железистным опушением, по всей длине. Листья (3-4) очередные, со спиральным расположением. Чешуевидный лист, если он есть, белого, со временем бурого цвета. Настоящие листья 11,5-17,5 см длиной, 4,0-10,2 см шириной, широкоэллиптические, эллиптические, заостренные, по жилкам и краю слегка волосистые. Соцветие 1 или 2 цветковое. Прицветники листовидные 8,5-13,2 см длиной, 3,6-7,2 см шириной; если прицветника два, то нижний, как правило, крупнее. Листочки околоцветника имеют значительный спектр окраски в розовых, пурпурных, буроватых, коричневых оттенках, чаще другого цветы чем губа. Синсепалум чаще двузубчатый, обычно узко-яйцевидный. Верхний листочек наружного круга 3,0-6,5 см длиной, 1,8-3,5 cм шириной. Листочки внутреннего круга неравнобокие, волнистые, ланцетные, 4,0-6,2 см длиной, 0,61,0 см шириной, длиннее губы. Губа имеет окрас бордово-коричневых, буровато-розовых оттенков до почти белого цвета, часто с более темными яркими жилками, 3,5-5,2 см длиной и 2,0-3,7 см шириной, с относительно небольшим отверстием со светложелтым окаймлением. Тычинки и стаминодий желтовато-белые, последний до 1,0-1,5 см длиной. Завязь железисто-опушенная, нескрученная 2,3-3,5 см длиной, 0,4-0,5 см шириной (рис. 1: 3-6).

Для оценки состояния видов проведено сравнение с литературными данными мерных (см) и счетных (шт.) морфологических признаков, описанных в процессе мониторинга (табл. 1).

Как видно из таблицы 1 , у C. calceolus все параметры, за исключением длины прицветника, входят в описанный диапазон. У двух других видов в изученном местообитании большинство параметров имеет более высокие значения. Для C. macranthon это высота генеративного побега, длина и ширина листа, длина и ширина прицветника, длина и ширина бокового листочка внутреннего круга околоцветника. Для C. $\times$ ventricosum - длина и ширина верхнего листочка наружного круга околоцветника, длина и ширина прицветника. Это позволяет сделать вывод, что эколого-ценотические условия исследуемого местообитания являются наиболее благоприятными для C. macranthon и $C . \times$ ventricosum.

Учитывая тот факт, что $C . \times$ ventricosum считается естественным гибридом C. macranthon и $C$. calceolus, можно также предположить, что склонность к образованию большого числа генеративных и вегетативных побегов он унаследовал от $C$. calceolus. 
Герасимович Л.В.

Род Cypripedium L. в уникальном местообитании орхидных

03.02.00 - общая биология

Количество побегов, образуемых растением за вегетационный период, как и их степень развития, у корневищных форм является показателем реального оптимума популяции [10]. Согласно данным методи- ческим разработкам, для оценки индивидуального организменного оптимума, который в своей сумме определяет оптимум всего вида, необходимо найти местообитания с высокой степень развития биомассы.
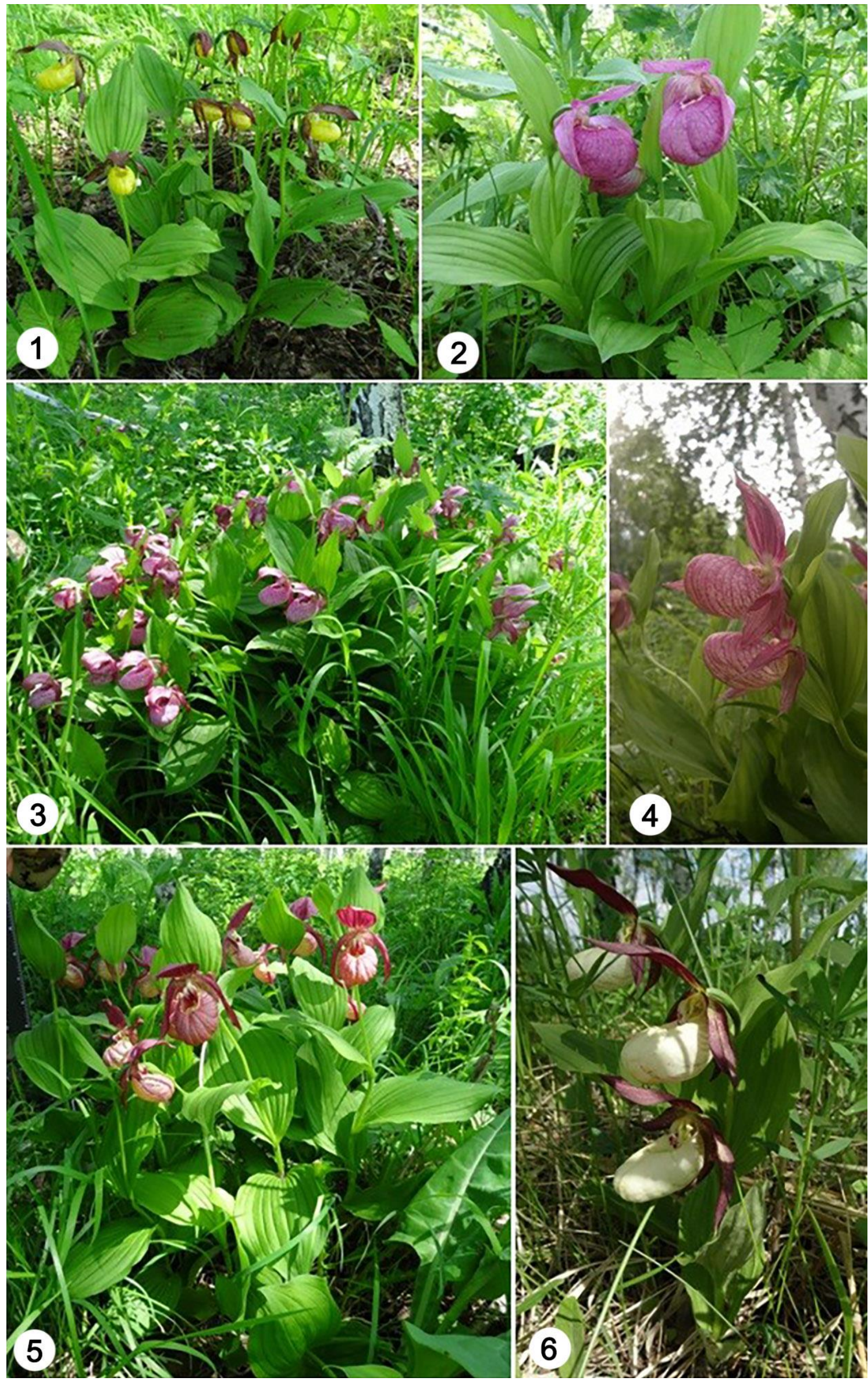

Рисунок 1 - 1-Cypripedium calceolus, 2-Cypripedium macranthon; 3-6-Cypripedium $\times$ ventricosum 
Таблица 1 - Морфологические признаки вегетативных и генеративных органов видов Cурripedium

\begin{tabular}{|c|c|c|c|c|}
\hline Морфологические признаки & $\begin{array}{c}\text { Флора Сибири, } \\
1987 \text { [21] }\end{array}$ & \begin{tabular}{|l|} 
Вахрамеева и \\
др., $2014[22]$
\end{tabular} & $\begin{array}{c}\text { Аверьянов, } \\
1999[13]\end{array}$ & $\begin{array}{c}\text { Данные } \\
\text { мониторинга }\end{array}$ \\
\hline \multicolumn{5}{|c|}{ Cypripedium calceolus } \\
\hline Высота генеративного побега, см & $20-50$ & $20-70$ & $(15) 20-50(60)$ & $30-60$ \\
\hline Число листьев, шт. & & $3-5$ & $(2) 3-4$ & $3-4$ \\
\hline Длина листа & $6-10(15)$ & до 20 & $(6) 10-16(20)$ & $13-15,5$ \\
\hline Ширина листа & $2-4(10)$ & до 10 & $(3) 3,5-8(12)$ & $4-10,5$ \\
\hline Число цветков на побеге, шт. & $1-2$ & $1(2-3)$ & $1-2(3)$ & $1-2$ \\
\hline Длина верхнего листочка наружного круга, см & & до 5 & $3,5-5(6,5)$ & $3,5-5,5$ \\
\hline $\begin{array}{l}\text { Ширина верхнего листочка наружного круга, } \\
\text { см }\end{array}$ & & до 2,5 & $1,2-1,8(2,2)$ & $1-2$ \\
\hline $\begin{array}{l}\text { Длина бокового листочка внутреннего круга, } \\
\text { см }\end{array}$ & $4-6$ & до 6 & $(2,5) 3,5-6(6,5)$ & $4-5,1$ \\
\hline $\begin{array}{l}\text { Ширина бокового листочка внутреннего круга, } \\
\text { см }\end{array}$ & $0,5-0,8$ & до 0,8 & $\begin{array}{c}(0,4) 0,5- \\
0,7(0,8)\end{array}$ & $0,4-0,5$ \\
\hline Длина губы, см & 3 & $3-3,5(4,5)$ & $(2,5) 3-3,5(4,5)$ & $3-3,5$ \\
\hline Ширина губы, см & & $2-2,5(3)$ & $(1,3) 2-2,5(3)$ & $1,5-2$ \\
\hline Длина прицветника, см & до 7 & $1-6(12)$ & $1-6(12)$ & $7,5-9,5$ \\
\hline Ширина прицветника, см & & $1,2-4(8)$ & $(0,8) 1,2-4(8)$ & $2,5-5,5$ \\
\hline Число генеративных побегов, шт. & & & & $1-6(26)$ \\
\hline Число вегетативных побегов, шт. & & & & $(0) 2-3(6)$ \\
\hline \multicolumn{5}{|c|}{ Cypripedium macranthon } \\
\hline Высота генеративного побега, см & $25-50$ & до 45 & $(10) 15-35(45)$ & 29-50 \\
\hline Число листьев, шт. & & $3-5$ & $(2) 3-4(5)$ & $3-5$ \\
\hline Длина листа & $8-16$ & до 18 & $(6) 8-16(20)$ & 11-19 \\
\hline Ширина листа & $4-8$ & до 11 & (3)4-8(10) & $5-12$ \\
\hline Число цветков на побеге, шт. & 1 & $1(2)$ & $1(2)$ & 1 \\
\hline Длина верхнего листочка наружного круга, см & $4-6$ & $4-6$ & $(2,5) 4-6$ & $4,5-5,2$ \\
\hline $\begin{array}{l}\text { Ширина верхнего листочка наружного круга, } \\
\text { см }\end{array}$ & $2,5-3,5$ & 3 & $(1) 2,5-3(4)$ & $3,3-4$ \\
\hline $\begin{array}{l}\text { Длина бокового листочка внутреннего круга, } \\
\text { см }\end{array}$ & $4-5$ & до 6 & $(2,5) 4-6$ & $4,9-6,5$ \\
\hline $\begin{array}{l}\text { Ширина бокового листочка внутреннего круга, } \\
\text { см }\end{array}$ & & до 2 & (1) $1,5-2,5$ & $1,9-2,7$ \\
\hline Длина губы, см & $4,5-7$ & до 7 & $(2,5) 4-5(6,5)$ & $4-6,5$ \\
\hline Ширина губы, см & $6-8$ & & $(1,5) 3-4(5)$ & $3-5$ \\
\hline Длина прицветника, см & $7-10$ & до 10 & $7-10(14)$ & 9-14,2 \\
\hline Ширина прицветника, см & $2,5-6$ & & $(2,5) 3-5,5(6)$ & $3,5-8,5$ \\
\hline Число генеративных побегов, шт. & & & & $3-5(11)$ \\
\hline Число вегетативных побегов, шт. & & & & $1-3$ \\
\hline \multicolumn{5}{|c|}{ Cypripedium $\times$ ventricosum } \\
\hline Высота генеративного побега, см & & $20-45(60)$ & $(15) 20-45(60)$ & $27-60$ \\
\hline Число листьев, шт. & & $3-4$ & $3-4$ & $3-4$ \\
\hline Длина листа & & $10-20$ & $(6) 10-16(20)$ & $11,5-17,5$ \\
\hline Ширина листа & & $4-8$ & $4-8(10)$ & $4-10,2$ \\
\hline Число цветков на побеге, шт. & & $1-2$ & $1-2$ & $1-2$ \\
\hline Длина верхнего листочка наружного круга, см & & $3,5-5$ & $(3) 3,5-5(6)$ & $3-6,5$ \\
\hline $\begin{array}{l}\text { Ширина верхнего листочка наружного круга, } \\
\text { см }\end{array}$ & & $1,5-3$ & $(1) 1,5-2,7(3,5)$ & $1,8-3,5$ \\
\hline $\begin{array}{l}\text { Длина бокового листочка внутреннего круга, } \\
\text { см }\end{array}$ & & 3,5 & $3,5-6(6,5)$ & $4-6,2$ \\
\hline $\begin{array}{l}\text { Ширина бокового листочка внутреннего круга, } \\
\text { см }\end{array}$ & & $0,6-1,2$ & $\begin{array}{c}(0,5) 0,6- \\
1,2(1,5)\end{array}$ & $0,6-1$ \\
\hline Длина губы, см & & $3-5$ & $(2,5) 3-5(5,5)$ & $3,5-5,2$ \\
\hline Ширина губы, см & & $2-3$ & $(1,5) 2-3(3,5)$ & $2-3,7$ \\
\hline Длина прицветника, см & & $3-8$ & $3-8(12)$ & $8,5-13,2$ \\
\hline Ширина прицветника, см & & $2,5-5$ & $(2) 2,5-5(6)$ & $3,6-7,2$ \\
\hline Число генеративных побегов, шт. & & & & $7-13(51)$ \\
\hline Число вегетативных побегов, шт. & & & & $1-2(7)$ \\
\hline
\end{tabular}


В связи с этим для мониторинга нами был выбран участок площадью $1340 \mathrm{~m}^{2}$, в котором можно выделить (рис. 2) своеобразное ядро - высокую степень концентрации двух видов, C. macranthon и C. calceolus, являющихся родительскими формами для C. $\times$ ventricosum.

Успешной межвидовой гибридизации могло способствовать такое приспособление C. calceolus к опылению, как длительность цветения. В литературе имеются указания на то, что в ожидании опыления продолжительность жизни цветка у данного вида достигает трех недель, но он сразу увядает при попадании пыльцы на рыльце пестика [22, с. 86, 94].

Как видно на карте (рис. 2), распространение растений $C . \times$ ventricosum преимущественно в одном направлении может быть связано, в том числе, и с анемохорией.

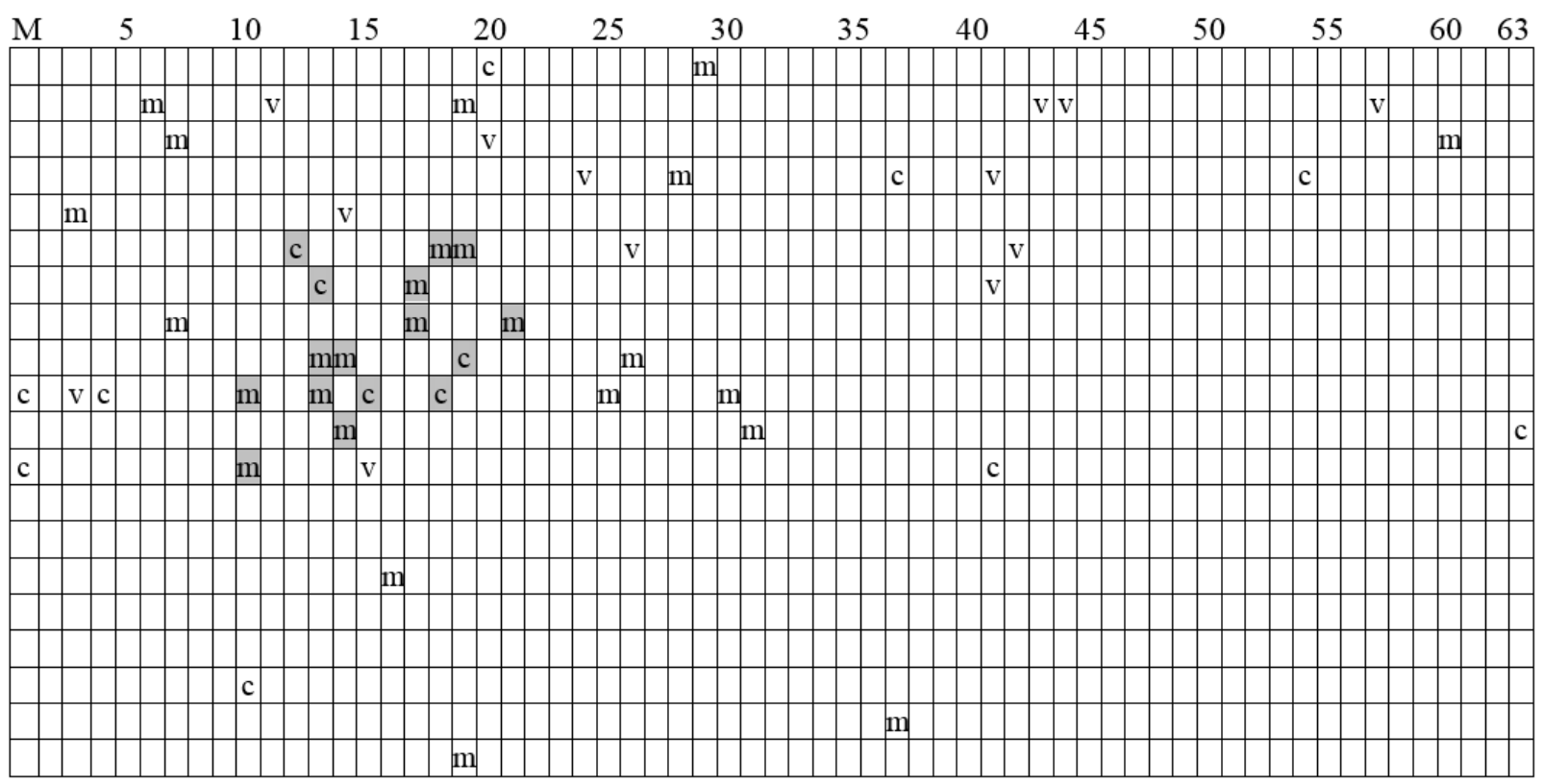

Рисунок 2 - Расположение генеративных особей C. calceolus (c), C. macranthon $(m)$ и C. x ventricosum (v) на учетной площадке

\section{Заключение}

В заключение следует отметить, что исследуемое местообитание с тринадцатью видами орхидных из родов Dactylorhiza Nevski, Epipactis Zinn, Gymnadenia R. Br., Herminium R. Br., Orchis L., Platanthera L.C.M. Rich., Cypripedium L. в Искитимском районе Новосибирской области является уникальным и требует срочных и радикальных мер по своей охране. Новый вид для Новосибирской области Cypripedium $\times$ ventricosum $\mathrm{Sw}$. предлагается включить в состав Красной книги Новосибирской области.

Автор выражает искреннюю признательность за доверие $u$ открытие данного местообитания Юрию Александровичу Панову, учителю биологии и экологии «Гимназии № 1 Искитимского района» Новосибирской области, руководителю экологического музея, а также Татьяне Викторовне Нагорных за оказанную помощьв в описании растений.

\section{Список литературы:}

1. Dressler R.L. The Orchids. Natural history and classification. 1981, London, Harvard Univ. Press. 390 s.

2. Ковтонюк Н.К. Семейство Orchidaceae Juss. // Конспект флоры Азиатской России: Сосудистые растения / Л.И. Малышев [и др.]; под. ред. К.С. Байкова. Новосибирск: Изд-во СО РАН, 2012. С. 447-456.

3. Герасимович Л.В. Орхидные (Orchidaceae) Горного Алтая. Новосибирск: Академ. изд-во «ГЕО», 2012. $120 \mathrm{c}$.

4. Красноборов И.М., Ломоносова М.Н., Шауло Д.Н. и др. Определитель растений Новосибирской области. Новосибирск: Наука. Сибирское предприятие PAH, 2000. 492 c.
5. Лащинский Н.Н., Лащинская Н.В. Высшие сосудистые растения // Флора Салаирского кряжа. Новосибирск, 2007. С. 155-251.

6. Filippov E.G., Andronova E.V. Genetic differentiation in plants of the genus Cypripedium from Russia inferred from allozyme data // Russian Journal of Genetics. 2011. Vol. 47, № 5. P. 538-545.

7. Работнов Т.А. Изучение ценотических популяций в целях выяснения стратегии жизни видов растений // Бюлл. МОИП. Отд. Биология. 1975. Т. 80, вып. 2. С. 5-17.

8. Уранов А.А. Возрастной спектр фитоценопопуляции как функция времени и энергетических волновых процессов // Биологические науки. 1975. № 2. С. 7-33.

9. Денисова Л.В., Никитина С.В., Заугольнова Л.Б. Программа и методика наблюдений за ценопопуляциями видов растений Красной книги СССР. М., 1986. 36 c.

10. Заугольнова Л.Б., Жукова А.А., Комарова А.С., Смирнова О.В. Ценопопуляции растений (очерки популяционной биологии). М.: Наука, 1988. 180 с.

11. Экологи предложили создать под Искитимом заповедник дикорастущих орхидей [Электронный pecypc] // Тайга.инфо. - https://tayga.info/127939.

12. Наумцев Ю.В., Лебедев А.Н. Редкие виды орхидных Тверской области в Ботаническом саду Тверского университета // Вестник Нижегородского университета им. Н.И. Лобачевского. 2014. № 3 (3). C. 97-100.

13. Аверьянов Л.В. Род Башмачок - Cypripedium (Orchidaceae) на территории России // Turczaninowia, 1999. Т. 2, вып. 2. С. 5-40. 
14. Linnaeus C. Species Plantarum, 1753, Imprensis Laurentii Salvii, Holmiae, 2 vols. Vol. 1: P. 1-560; Vol. 2: P. 561-1200.

15. Невский С.A. Orchidaceae Lindl // Флора СССР. М.; Л.: АН СССР, 1935. Т. 4. С. 589-730.

16. Иванова Е.В. Сем. Orchidaceae // Флора Сибири. Araceae-Orchidaceae. Новосибирск: Наука, 1987. T. 4. C. $125-145$.

17. Красноборов И.М., Крапивкина Э.Д., Ломоносова М.Н. и др. Определитель растений Кемеровской области. Новосибирск: Издательство СО РАН, 2001. $477 \mathrm{c}$.

18. Красноборов И.М., Ломоносова М.Н., Шауло Д.Н. и др. Определитель растений Алтайского края. Новосибирск: Издательство СО РАН, филиал «Гео», 2003. $634 \mathrm{c}$.
19. Пяк А.И. Сем. Орхидные - Orhidaceae // Определитель растений Томской области. Томск: Издательство Томского университета, 2014. С. 342-351.

20. Swsrtz O. Orchidernes, 1800, Kongl. Vetenskaps Academiens Nya Handlingarpp. Vol. 21. P. 202-254.

21. Доронькин В.М. Сем. Orchidaceae // Флора Сибири. Новосибирск: Наука, 2003. Т. 14. С. 35-37.

22. Вахрамеева М.Г., Варлыгина Т.И., Татаренко И.В. Орхидные России (биология, экология и охрана). М.: Товарищество научных издательств КМК, 2014. $437 \mathrm{c}$.

Исследования выполнены в рамках проекта VI.52.1.3. «Выявление путей адаптации растений к контрастным условиям обитания на популяционном и организменном уровнях". Номер госрегистрации АAAA-A17-117012610053-9.

\section{THE GENUS CYPRIPEDIUM L. IN THE UNIQUE HABITAT OF ORCHIDS IN THE NOVOSIBIRSK REGION}

(C) 2018

Gerasimovich Lyudmila Vladimirovna, candidate of biological sciences, junior researcher of Ornamental Plants Introduction Laboratory

Central Siberian Botanical Garden of Siberian Branch of Russian Academy of Sciences (Novosibirsk, Russian Federation)

Abstract. This paper provides information about the unique habitat, where 13 species of orchids of the genera Dactylorhiza Nevski, Epipactis Zinn, Gymnadenia R. Br., Herminium R. Br., Orchis L., Platanthera L.C.M. Rich., Cypripedium L. grow in Iskitim District of the Novosibirsk Region. A morphological description of three kinds of shoes is given, including a new for the Novosibirsk Region species Cypripedium $\times$ ventricosum Sw., which is proposed to be included in the Red Book of the Novosibirsk Region. The investigated community of shoes is located in a birch-high-herbage forest, in the Koyniha river basin. Comparison of the characteristics of the vegetative and generative organs Cypripedium x ventricosum Sw., Cypripedium calceolus $\mathrm{L}$. and Cypripedium macranthon Sw, described as a result of monitoring, is compared with literary data. It was shown that all parameters of C. calceolus, except for the bract length (greater than average), are included in the described range. In the studied habitat, most of the parameters of $C$. macranthon and $C$. $\times$ ventricosum (the length and width of the bract, the length and width of the lateral leaf of the perianth of the inner circle) have higher values. It allows us to conclude that the eco-cenotic conditions of the studied habitat are most favorable for C. macranthon and $C . \times$ ventricosum. Cenopopulations of all three species exist for a fairly long period and are in their real optimum.

Keywords: Orchidaceae Juss. family; Cypripedium x ventricosum Sw.; Cypripedium calceolus L.; Cypripedium macranthon Sw.; new kind for Novosibirsk Region; Iskitimsky District; comparative morphology; monitoring; protection of rare species; Red Book of Novosibirsk Region.

УДК 631.2/3.03:631. 531.06

DOI 10.24411/2309-4370-2018-14105

Статья поступила в редакцию 03.06.2018

\section{РЕПРОДУКТИВНЫЕ ОСОБЕННОСТИ FESTUCA RUBRA L. В РАЗНЫХ ЭКОЛОГИЧЕСКИХ УСЛОВИЯХ}

Зуева Галина Александровна, кандидат биологических наук, старший научный сотрудник лаборатории интродукции декоративных растений Центральный сибирский ботанический сад СО РАН (2. Новосибирск, Российская Федерация) Хусаинова Ирина Викторовна, научный сотрудник лаборатории интродукции Институт ботаники и фитоинтродукичи (2. Алматы, Республика Казахстан)

Аннотация. В работе представлены сравнительные результаты изучения семенной продуктивности Festuca rubra L. в условиях Сибири и Казахстана. Рассмотрено влияние экологических условий на органообразовательный процесс вида. Выявлены особенности роста и развития растений при разных сроках высева в разных экологических условиях. В первый год вегетации растения во всех вариантах проходят две фенологические фазы - всходы и кущение. Разные сроки посева вносят существенные изменения в репродуктивную способность растений. У растений весеннего посева верхушечная меристема в конце вегетационного периода соответствует IV этапу органогенеза. Весной следующего года побеги 2-го, 3-го и 4-го порядков тоже переходят в генеративное развитие. Определен оптимальный способ выращивания Festuca rubra с максимальными показателями семенной продуктивности. Выяснено, что при весеннем посеве максимальный урожай семян (до 48 г $\left./ \mathrm{M}^{2}\right)$ можно получить на третий год жизни злака. На четвертый год наблюдается небольшое сни- 